\title{
A Comparison: Composite Index of Anthropometric Failure (CIAF) Incidence in Bukittinggi City and Dharmasraya District, Indonesia
}

\author{
Azrimaidaliza ${ }^{1}$, Welly Femelia ${ }^{2}$, Sukarsi Rusti ${ }^{3}$, Resmiati $^{4}$, Nadia Chalida Nur ${ }^{5}$ \\ \{ azrimaidaliza75@gmail.com¹,b3.w311@gmail.com² \\ rustiuci@gmail.com ${ }^{3}$, resmiati89@gmail.com ${ }^{4}$,nadiachalid269@gmail.com $\left.{ }^{5}\right\}$ \\ 1,2,4,5Faculty of Public Health, Andalas University, Padang, Indonesia \\ ${ }^{3}$ Faculty of Public Health Fort De Kock University, Bukittinggi, Indonesia
}

\begin{abstract}
Malnutrition that occurs in an early period of life led to the vulnerable to diseases, cognitive disorder, and failed to thrive. Failed to thrive happened when the result of anthropometric measurement indicates a problem. If the problem showed in two or more indexes, it is called CIAF. In Indonesia, one of ten children had suffered from CIAF (9,3\%). Cities or districts in Indonesia use only a single index, so the data of CIAF is not available. He objective of the study was to compare the incidence of CIAF in one city and district in Indonesia. A cross-sectional design applied in this study with the number of the sample was 196 children aged $2-5$ years, every 98 children in Bukittinggi City and Dharmasraya District. There were $22,45 \%$ of children suffered from CIAF in Bukittinggi, slightly different in Dharmasraya, which is $21,40 \%$. The cases mostly happen to the girls in both places in the form of wasted - stunted. The number of normal children was higher in the city better than in the district region. There is no significant difference in the number of CIAF incidence in the city or the district region. The nutritional status of children is better in the city. The mother was to be expected to pay more attention to the girl's nutrition because they tended to suffer nutritional problems. Provide enough food and protection from the disease are essential to keep their nutritional status in the optimal condition.
\end{abstract}

Keywords: CIAF, city, comparison, district

\section{Introduction}

Malnutrition is responsible for morbidity compared with other causes [1]. Poor nutrition can lead to health problems across generations, especially in vulnerable populations[2]. Malnutrition occurs when the child is in the womb, and early life causes the fetus to make adjustments. These adjustments include slowing growth by reducing the number and development of body cells, including brain cells and other organs. This adjustment will have an impact on the small body, low cognitive abilities, and an increased risk of noncommunicable diseases [3].

Short bodies in adulthood, especially in women, will tend to give birth to short children. This situation will be repeated so that there are problems with nutrition across generations. While being overweight will be at risk for non-communicable diseases [3]. Therefore, in the 
Sustainable Development Goals (SDGs), efforts are made to end all forms of malnutrition. Consequently, the government plans various initiatives related to improving nutritional status [4]

Low-income countries are recommended to use Z-scores in analyzing anthropometric measurement data [5]. In Indonesia, anthropometric nutritional status measurements are carried out using the $\mathrm{BB} / \mathrm{U}$ index, $\mathrm{TB} / \mathrm{U}$, and $\mathrm{BB} / \mathrm{TB}[6]$. More comprehensive results can be obtained by using all three indices simultaneously. Problematic conditions that are found in more than one index are called the failure of the composite anthropometry or the Composite Index of Anthropometric Failure (CIAF). The CIAF case can be in the form of under-short nutrition, under-thin nutrition, short-underweight, short-fat, and under-short-thin nutrition [7]

Children who suffer from CIAF have a higher risk of death than healthy children. Children who are short and malnourished (not thin) are at risk 3.4 times more likely to die while children who are thin and malnourished (not short) are at 4.7 times greater risk. The highest risk (12.3 times) occurs in short children - malnourished - thin [7]

CIAF generally occurs in developing countries and is almost not found in developed countries. In Ethiopia, the incidence of multiple anthropometric-failure was $44.63 \%$ [8]. Whereas in India, the prevalence is lower at $36 \%$ and $31.8 \%$ [9]

Nationally, the number of combined nutritional problems in toddlers is short $-2.5 \%$ thin and short - fat $6.8 \%$. There are $9.3 \%$ of children in Indonesia suffering from at least two nutritional problems [10]. When combined with the prevalence of single nutritional problems, the total number of cases is $51.4 \%$. Thus, only $48.6 \%$ of children under five in Indonesia are free from nutrition problems.

The majority of the population in Indonesia has deficient levels of energy sufficiency $(45.7 \%)$ and less $(33.9 \%)$. West Sumatra Province is in a position not far from the national figure of $41 \%$ (very less) and 39\% (less). As for children under five, the average energy intake is $1137 \mathrm{kcal}$ (recommended $1118 \mathrm{kcal}$ ). West Sumatra Province is one of the provinces with Energy Adequacy Figures (AKE) in children under five classified as very poor [11].

Research conducted by Fentahun et al. (2016) in Ethiopia shows that the incidence of CIAF is influenced by one of them by the sex of the child (OR = 7.4). In the same country, Abate and Belachew (2017) found that the prevalence of stunting was $19.7 \%$ and wasting was $8.8 \%$ while the factors that influence it are the sex of the child (for wasting and stunting), maternal autonomy (for wasting only), and father's involvement in care (stunting only).

\section{Method}

This research was conducted in the City of Bukittinggi and the Regency of Dharmasraya. These two regions were chosen as representatives of the urban and rural areas. The design used in this study was cross-sectional. Data collection in Bukittinggi City was carried out in 2018 while in Dharmasraya District, it began in 2019. The study population was toddlers aged 2-5 years who had been weaned by their mothers (stopped breastfeeding) and were able to stand alone.

In the city area, the population is 3510 children, and in the village, there are 1491 children. In each region, randomly 98 children were taken. This research was conducted by measuring the height and weight of children using microtome and stepping scales. The questionnaire was prepared to contain the identity of the child and the mother as well as 
several questions related to child nutrition. Data analysis was performed descriptively to obtain the number of cases in each region as well as a description of sample characteristics.

\section{Result}

The number of samples in this study was 196 children and their mothers. Based on table 1 , it can be concluded that the majority of mothers of children under five in cities or villages are more than 30 years old. Generally, they have completed Senior High School or Higher Education (PT), but they do not have a job (housewife).

The children who were respondents were generally female. In urban areas, children are usually younger than three years, while in rural areas the most group is children aged 3-4 years. Similar conditions in both regions, child respondents are the first or second child in the family.

Tabel 1. Characteristics of Respondents

\begin{tabular}{|c|c|c|c|c|}
\hline \multirow{3}{*}{$\begin{array}{c}\text { Characteristics of Respondents } \\
\text { Mother }\end{array}$} & \multicolumn{4}{|c|}{ Area } \\
\hline & \multicolumn{2}{|c|}{ Bukittinggi } & \multicolumn{2}{|c|}{ Dharmasraya } \\
\hline & $\mathbf{N}$ & $\%$ & $\mathbf{n}$ & $\%$ \\
\hline \multicolumn{5}{|l|}{ Age } \\
\hline$-\leq 30$ years & 22 & 22,40 & 44 & 44,90 \\
\hline - $>30$ years & 76 & 77,60 & 54 & 55,10 \\
\hline \multicolumn{5}{|l|}{ Education } \\
\hline - Low & 23 & 23,50 & 33 & 33,70 \\
\hline - High & 75 & 76,50 & 65 & 66,30 \\
\hline \multicolumn{5}{|l|}{ Occupation } \\
\hline - Formal & 26 & 26,53 & 20 & 20,41 \\
\hline - Informal & 10 & 10,20 & 10 & 10,20 \\
\hline - Not employee & 62 & 63,26 & 68 & 69,39 \\
\hline \multicolumn{5}{|l|}{ Children } \\
\hline \multicolumn{5}{|l|}{ Sex } \\
\hline - Male & 44 & 44,90 & 36 & 36,73 \\
\hline - Female & 54 & 55,10 & 62 & 63,27 \\
\hline \multicolumn{5}{|l|}{ Age } \\
\hline$-\leq 36$ months & 45 & 45,90 & 34 & 34,70 \\
\hline$-\overline{3} 7-48$ months & 26 & 26,50 & 46 & 46,94 \\
\hline$-\geq 49$ months & 27 & 27,60 & 18 & 16,36 \\
\hline \multicolumn{5}{|l|}{ Number of Birth } \\
\hline$-\leq 2$ & 74 & 75,5 & 65 & 66,30 \\
\hline$->2$ & 24 & 24,5 & 33 & 33,67 \\
\hline
\end{tabular}

It was further found that as many as $22.45 \%$ of children under five in Bukittinggi City experienced CIAF. Slightly lower, in Dharmasraya District, there were $21.42 \%$ of children with CIAF. In both regions, the most common combination of problems was short - thin. Cases with a combination of three problems were found more in urban areas. Children who have problems with just one anthropometric index are mostly found in villages. Overall, the 
number of children with normal nutritional status was found more in cities, namely $55.11 \%$ while in villages, only $45.91 \%$.

Table 2. CIAF Incident

\begin{tabular}{|c|c|c|c|c|}
\hline \multirow{3}{*}{ Variable } & \multicolumn{4}{|c|}{ Area } \\
\hline & \multicolumn{2}{|c|}{ Bukittinggi } & \multicolumn{2}{|c|}{ Dharmasrava } \\
\hline & $\mathbf{N}$ & $\%$ & n & $\%$ \\
\hline \multicolumn{5}{|l|}{ CIAF Incident } \\
\hline \multirow[t]{2}{*}{ Yes } & 22 & 22,45 & 21 & 21,42 \\
\hline & 20 & 20,41 & 20 & 20,40 \\
\hline \multicolumn{5}{|l|}{ - Double } \\
\hline \multirow[t]{2}{*}{ - Triple } & 2 & 2,04 & 1 & 1,02 \\
\hline & 75 & $\mathbf{7 7 , 5 3}$ & 77 & $\mathbf{7 8 , 5 8}$ \\
\hline \multirow[t]{2}{*}{ No } & 21 & 21,42 & 32 & 32,66 \\
\hline & 54 & 55,11 & 45 & 45,92 \\
\hline \multicolumn{5}{|l|}{$\begin{array}{l}\text { - Single } \\
\text { - Normal }\end{array}$} \\
\hline Total & 98 & 100 & 98 & 100 \\
\hline
\end{tabular}

In the Bukitinggi, children who experience CIAF are in the age range 29 - 59 months and are generally female. Most cases occur at $\leq 44$ months of age. The age of the mother of these cases is in the range of 25-43 years. More than half of the cases were reported in children with young mothers who are under 30 years of age. As for education, children with CIAF cases generally have highly educated mothers but do not work.

In the village areas, children who experience CIAF are in a younger age range of 25 - 52 months and are generally female. Overall, more than half of the cases occurred at $\leq 38$ months. The age of the mother of these cases is in the range of 25-43 years. Most cases were found in mothers aged $\geq 30$ years. Mother's education is high, but daily activities are housewives.

\section{Discussion}

Anthropometric measurements using three indices at the same time will produce interpretations in the form of malnutrition, malnutrition, malnutrition, malnutrition, shortness, fatness, normality, and malnutrition. A child is said to experience failure of combined anthropometry or CIAF if the measurement results show problems at two or more indices [7]. It means that when measurements are taken, the interpretation of the results with the combination problem is obtained. This combination can be short-fat, short-thin, under-short nutrition, under-thin nutrition, and so forth. Problems like this are more complex when compared to individuals who only have problems with one anthropometric index.

In Indonesia, the combined figure for all forms of CIAF cases is 9.3\% [10]. This study found a much higher number, both in urban and rural areas. Nutritional problems in many cities or villages are also different from conditions at the national level, namely short - thin. Children with short-fat nutritional status are found in minimal amounts.

Both in the Bukittinggi and Dharmasraya, the CIAF case many cases occur in girls from small families with highly educated mothers who do not work. In cities, CIAF cases appear more slowly than in villages. The first case occurred in children aged 29 months while in the 
village, the first case occurred in children aged 25 months. Even though most of the mothers in the village are housewives, more people work than mothers in the city. Many of them work in the informal sector, such as farmers or traders. Busy mothers outside the home can be one of the causes of the rapid emergence of CIAF cases in children in the village [12]

Although most of the mothers who become respondents are aged over 30 years, in cities, more cases are found in young mothers $(<30$ years). It can be sourced from the mother's lack of experience in caring for children so that the nutrition given to the child does not match the child's needs. In rural areas, more cases occur in mothers aged over 30 years. It is suspected that the cause is a large number of children in the family so that intake for toddlers is reduced.

Gupta et al.'s study of 100 children in the city of Delhi found that most children in the city had CIAF (62\%). This figure is much higher compared to the findings in this study. As is the case with this study, the majority of cases occur in children under three years old [13]. In the same year, Kherde et al. conducted a study in Nagpur, India. The CIAF incidence in the region is almost the same as the results of this study which is $23.26 \%$ [14][15]

The number of short - thin children in cities or villages shows that nutritional problems that occur are complex and acute - chronic. The unique problematic condition is found in many children who have highly educated mothers and are not economically productive (more at home). Only a small proportion of children have suffered from infectious diseases in the past three months. Therefore, consumption factors and parenting are thought to be an important part in the emergence of this case.

Healthy eating and living habits must be had at an early age because this will affect future living habits. Prefers healthy food and healthy eating patterns are important stages in a child's development. Malnutrition during this period will result in impaired cognition and the ability of children to explore their environment. It can be prevented and reduced through balanced nutrition and environmental support [16].

\section{Conclusion}

It can be concluded that there is no significant difference in the number of CIAF cases in cities and villages. Age under 36 months is a vulnerable age for experiencing CIAF. In both areas, the CIAF case has the same pattern, which is generally suffered by girls from small families (consisting of only two children). A slightly different phenomenon is seen from the early age of the emergence of the case. In villages, CIAF cases occur at a younger age with mothers over 30 years old, whereas in cities, CIAF cases occur more slowly and under the care of mothers under 30 years old. So expect mothers to pay special attention to the nutrition of girls so that their nutritional status is at optimal conditions. This can be sought through adequate and varied feeding and providing a clean environment so that children avoid infection.

\section{Acknowledgement}

This research can be carried out through full funding from Kemenristekdikti and Andalas University. 


\section{References}

[1] WHO, Global Nutrition Report: Shining a Light to Spur Action on Nutrition. Geneva, 2018.

[2] WHO, Knowledge Summary: Women's\&Children's Health, 18\# Nutrition. Geneva, 2012.

[3] Bappenas, Kerangka kebijakan gerakan sadar gizi dalam rangka 1000 Hari Pertama Kehidupan (1000 HPK). Jakarta, 2012.

[4] SDG's 2020, “Tujuan 02." [Online]. Available: https://www.sdg2030indonesia.org/page/10-tujuan-dua. [Accessed: 07-Jan-2020].

[5] R. . Gibson, Principles of Nutritional Assessment, 2nd ed. New York: Oxford University, 2005.

[6] Keputusan Menteri Kesehatan, Keputusan Meneteri Kesehatan Nomor 1995 tahun 2010 tentang Standar Antropometri Penilaian Status Gizi anak. Jakarta, 2010.

[7] C. M. McDonald et al., "The effect of multiple anthropometric deficits on child mortality: Meta-analysis of individual data in 10 prospective studies from developing countries," Am. J. Clin. Nutr., vol. 97, no. 4, pp. 896-901, Apr. 2013, doi: 10.3945/ajen.112.047639.

[8] N. Fentahun, T. Belachew, and C. Lachat, "Determinants and morbidities of multiple anthropometric deficits in southwest rural Ethiopia," Nutrition, vol. 32, no. 11-12, pp. 1243-1249, Dec. 2016, doi: 10.1016/j.nut.2016.03.023.

[9] D. Aparajita, K. Sanjaya, T. PPranita, and B. Dhiraj, "Composite index of Anthropometric Failure and Its Important Correlates: A Study Among Under - 5 Children In A Slum Kolkata, West Bengal, India," Int. J. Med. Sci. Public Heal., vol. 4, 2015, doi: 10.5455/ijmsph.2015.0111201485.

[10] Badan Penelitian dan Pengembangan Kesehatan, "Riset Kesehatan Dasar (RISKESDAS) 2013,” BADAN Penelit. DAN Pengemb. Kesehat. Kementeri. Kesehat. RI TAHUN 2013, 2013, doi: 1 Desember 2013.

[11] Kementerian Kesehatan RI, Survei Diet Total. Jakarta: Badan Penelitian dan Pengembangan, 2014.

[12] N. Zhang, L. Bécares, and T. Chandola, "Patterns and Determinants of Double-Burden of Malnutrition among Rural Children: Evidence from China," PLoS One, vol. 11, no. 7, p. e0158119, Jul. 2016, doi: 10.1371/journal.pone.0158119.

[13] G. Gupta, A. K. Sharma, and T. S. Choudhary, "Assessment of undernutrition among children below 5, using composite index of anthropometric failure (CIAF)," Indian J. Community Heal., vol. 29, no. 1, pp. 108-113, 2017.

[14] A. Kherde, C. R. Patil, J. Deshmukh, and P. B. Petkar, "Composite index of anthropometric failure among under 5 children attending the Immunoprophylaxis clinic in a tertiary care hospital in Nagpur, Maharashtra, India," Int. J. Contemp. Pediatr., vol. 5, no. 3, p. 888, Apr. 2018, doi: 10.18203/2349-3291.ijcp20181508.

[15] K. Chen et al., "Effect of vitamin A , vitamin A plus iron and multiple micronutrientfortified seasoning powder on infectious morbidity of preschool children," Nutrition, vol. 27, no. 4, pp. 428-434, 2011, doi: 10.1016/j.nut.2010.04.004.

[16] B. Judith E, NUTRITION THROUGH THE LIFE CYCLE, Third Edit. Belmont: Wadsworth, 2008. 